\title{
Baobabs, Adansonia spp. (Bombacaceae Malvaceae), around Antsiranana (Diego Suarez), northern Madagascar
}

\author{
R. Trevor Wilson
}

Bartridge House, Umberleigh, UK, EX37 9AS; e-mail: trevorbart@aol.com

\begin{abstract}
Baobabs list eight species of the genus Adansonia L. (Bombacaceae Malvaceae). One species is endemic to mainland Africa, one to Australia and six to Madagascar. Three Malagasy species are classed by IUCN as Lower Risk/Near Threatened and three are Endangered with limited numbers under the criteria of Extent of Occurrence and Area of Occupancy. The Antsiranana (Diego Suarez) region in northern Madagascar is home to A. madagascariensis Baill., A. suarezensis H. Perrier and A. perrieri Capuron. These are threatened by multiple causes. Naturally low regeneration rates, deforestation, use of fuelwood and charcoal, commercial logging, livestock grazing, collection and consumption of fruit, seed collection for use in cosmetics manufacture, and illegal fires are among these threats. Ecological (unable to regenerate in situ) if not physical extinction is possible because of the low regeneration potential. In addition to direct and immediate threats, the species are vulnerable to long term climate change. Small and fragmented populations, human-wildlife conflict, climate change, invasive species, diseases, lack of conservation law enforcement and inadequate knowledge and research make the prognosis for the survival of this part of Madagascar's heritage and biodiversity not very positive.
\end{abstract}

KEY WORDS Adansonia madagascariensis; A. perrieri; A. suarezensis; endemic species; Malvaceae.

Received 25.10.2018; accepted 10.11.2018; printed 30.12.2018; published online 07.01.2019

\section{INTRODUCTION}

The genus Adansonia L. (formerly Bombacaceae, family Malvaceae) includes eight species (Baum, 1995; Wickens \& Lowe, 2008). With one exception, the species are referred to in most western languages as baobab. The single indigenous mainland African species, A. digitata L., was described from Senegal following its "discovery" by the Frenchman after whom the genus is named (Adanson, 1791). A single Australian species, A. gregorii F. Muell., is commonly known as the boab: its specific name commemorates the explorer Augustus Gregory (Mueller, 1857; 1858: quoted in Baum, 1995).
The remaining six Adansonia species are native to Madagascar. Little - indeed almost totally - unknown until the beginning of the twentieth century, as knowledge at that time was aptly summarised as "Except for Adansonia madagascariensis [...] there are other species in the genus that are still largely unknown and about which, in view of our present lack of adequate material for study, we can provide little useful information. It is therefore recommended that these species be given greater attention by explorers of this large island." (Baillon, 1890).

Adansonia grandidieri Baill. is perhaps the iconic species and is found in the drier areas southwest of Madagascar. It is considered "endangered" 
(Ravaomanalina \& Razafimanahaka, 2016) although a recent population estimate is in excess of one million individuals (Vieilledent et al., 2013). Adansonia za Baill. occurs through southern and western Madagascar in dry or spiny forest, savannahs and scrubland. There are fewer numbers in the north-west, where it is restricted to riverine areas. Its relative abundance and wide range do not put the species at severe risk and it is classified by IUCN as Lower Risk/Near Threatened (World Conservation Monitoring Centre, 1998a). The specific epithet " $z a$ " is Malagasy for the tree. Occurring from the south-west to the north-west along the western coast, A. rubrostipa Jum. et Perr. is found in spiny and dry forest areas. Its wide distribution means it is not at immediate risk and it is classified by IUCN as Lower Risk/Near Threatened (World Conservation Monitoring Centre, 1998b). This species was initially and provisionally named $A$. fony towards the end of the nineteenth century (Baillon, 1890).

First described in the mid 1870s (Baillon, 1876) and the first Madagascar baobab to be named, the range of $A$. madagascariensis Baill. extends from Antsiranana southwards to dry or moist forest. In 1998 it was considered as Lower Risk/Near Threatened (World Conservation Monitoring Centre, 1998c). Adansonia suarezensis H. Perrier occurs on a very small area west of Antsiranana (Diego Suarez) in the Baie d'Antsiranana (Diego Suarez Bay) usually on limestone soils (Baum, 1995). Its area of distribution is within the limits for Endangered status under both the Extent of Occurrence and Area of Occupancy criteria of the IUCN. Three subpopulations occur outside protected areas with another three within (designated but not necessarily established) protected areas (World Conservation Monitoring Centre, 2017). Confined to the northern tip of Madagascar, A. perrieri Capuron is known from five sites, only one of which has more than twelve trees. This species, not described until 1960 (Capuron, 1960), is endangered (World Conservation Monitoring Centre, 1998d).

\section{MATERIAL AND METHODS}

A review of the relevant literature pertaining to baobabs was undertaken with emphasis on the Madagascar species. A series of road transects was made in March 2018 in the Antsiranana region
(Diego Suarez prior to 1975 in the approximate location of $12^{\circ} \mathrm{S}, 49^{\circ} \mathrm{E}$. Transects covered the area around Diego Suarez Bay), to the north of the provincial city, to the west and southwest and in the Parc National de Montagne d'Ambre. One transect was made at the foot of Montagne d'Ambre, but the southerly area of distribution of $A$. perrieri was not otherwise covered (Fig. 1).

\section{RESULTS AND DISCUSSION}

Prior to 1995 these northen species were largely sympatric in their distribution (Fig. 1; Baum, 1995).

Adansonia madagascariensis had the widest distribution and as such was considered to be near threatened and at lower risk than the other species. The distribution of $A$. suarezensis was much more restricted than $A$. madagascariensis and it was limited to a few sites to the west of Diego Suarez Bay: in part because of its restricted distribution, but also because it was heavily exploited for fruit and timber, it was considered endangered and liable to early extinction. Due to its very restricted distribution, exploitation for wood and charcoal, eating of seeds by introduced rats, and fire, $A$. perrieri was considered the most endangered of all Malagasy baobabs.

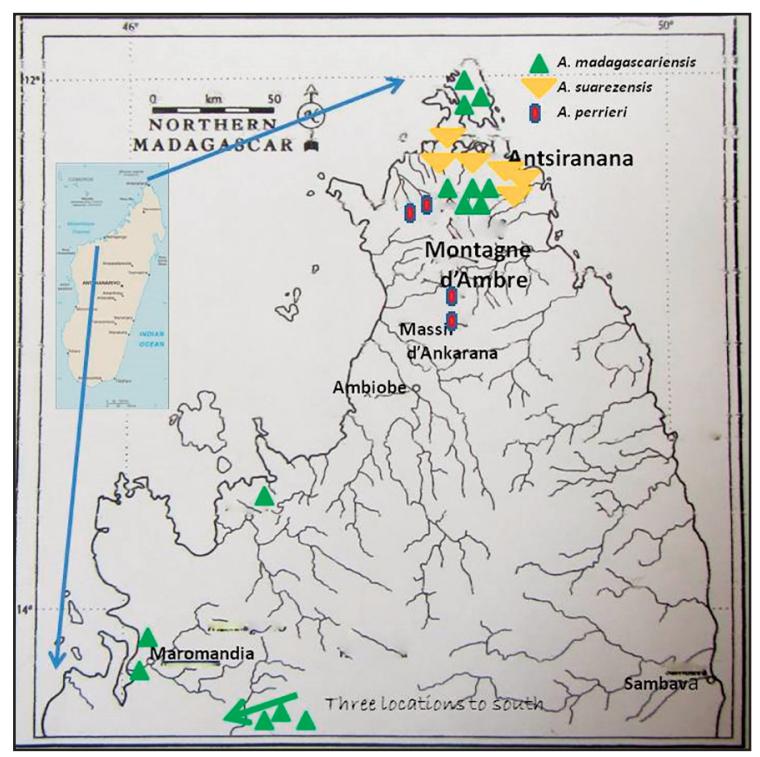

Figure 1. Outline map of northern Madagascar showing distribution of three Adansonia species in 1995 (adapted from Baum, 1995). 


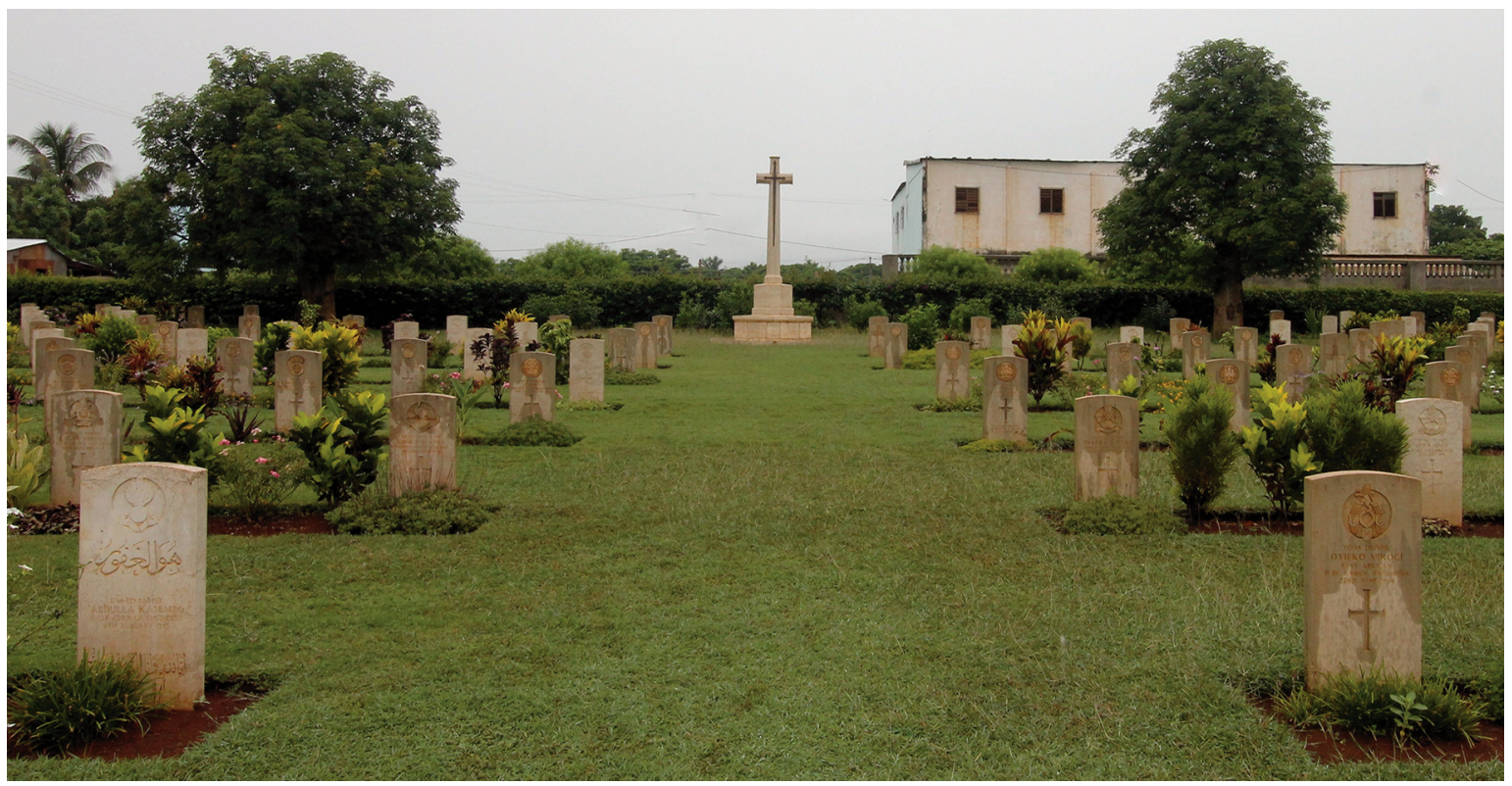

Figure 2. Adansonia madagascariensis planted about 1950 in the Diego Suarez Cemetery of the Commonwealth War Graves Commission; location 12¹7'16.22”S; 49¹7’47.42”E (photo by author).

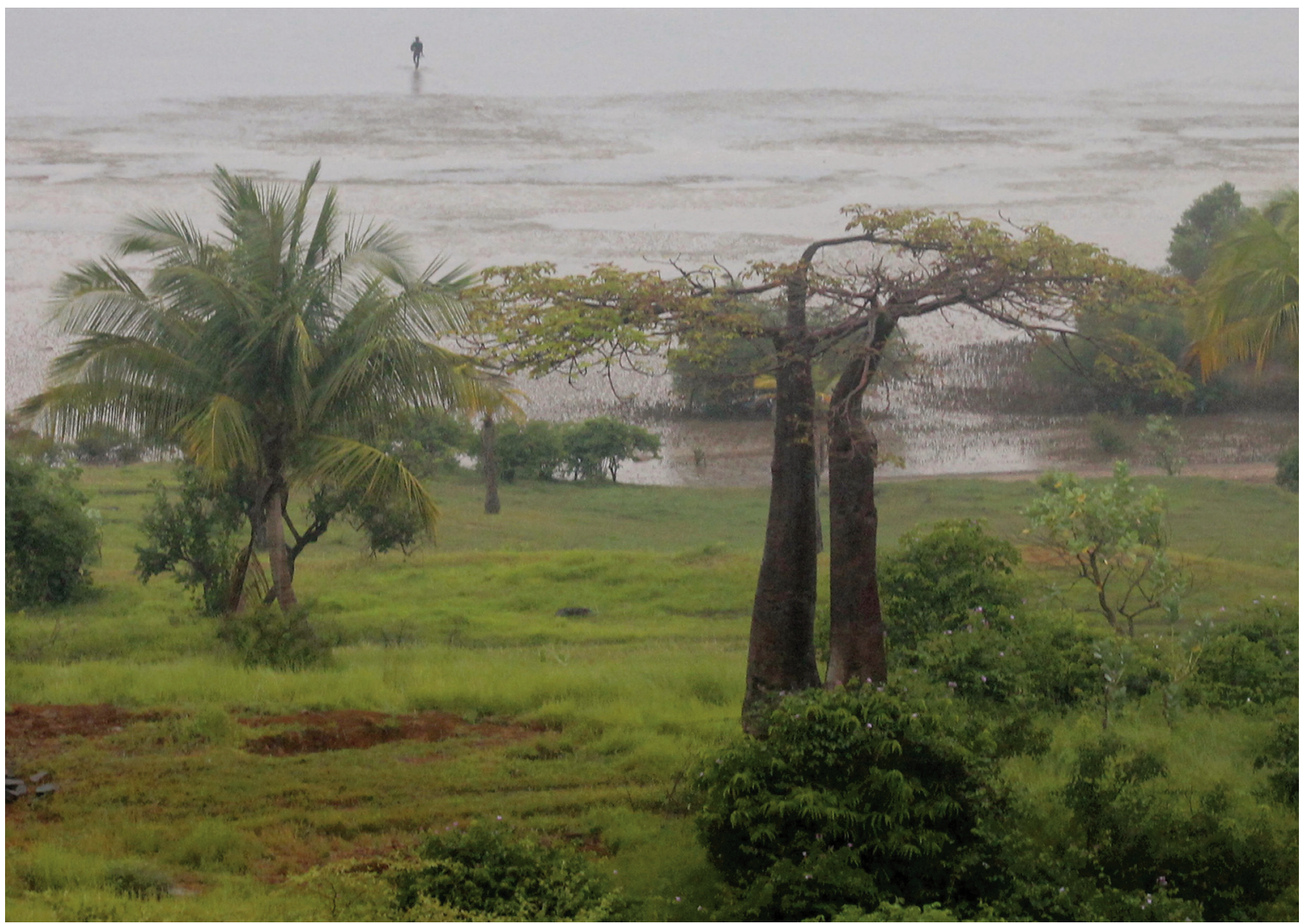

Figure 3. Adansonia suarezensis on the shore line of Diego Suarez Bay in front of the "sugar loaf" volcanic plug; location $12^{\circ} 18^{\prime} 52.89^{\prime \prime}$; $49^{\circ} 19^{\prime} 7.42$ ”E (photo by author). 
During the course of this recent field study very few baobabs were seen. Among these, there were a pair of A. madagascariensis that had been planted some 70 years ago (i.e., around 1950) in the Diego Suarez Cemetery of the Commonwealth War Graves Commission (Fig. 2). Two specimens of $A$. suarezensis were located on the shore line of the Bay in an area cleared for cultivation and production of oil palm (Fig. 3).

Madagascar's northen baobabs are threatened by a multiplicity of causes. Deforestation in the area of occurrence has been intense since 1953 and this is likely to continue. Baobabs have a naturally low regeneration rate that is compounded by livestock grazing on seedlings, collection and consumption of fruit by people, seed collection for use in cosmetics manufacture and fires, either accidental or set by hunters to clear areas for illegal poaching of wildlife. Exploitation for fuelwood and charcoal for local household use and logging for commercial purposes are additional threats. Ecological extinction (unable to regenerate in situ) if not physical extinction is possible because of the low regeneration potential (Baum, 1995). In addition to direct and immediate threats the species are vulnerable to long term climate change (Vieilledent et al., 2013). This study shows that $A$. suarezensis in particular is vulnerable to climate change and more than half the population in the future (the years 2050 to 2080) will be in areas unsuitable for the species.

Small and fragmented populations, humanwildlife conflict, climate change, invasive species, diseases, lack of enforcement of conservation laws, and inadequate knowledge and research make the prognosis for the survival of this part of Madagascar's heritage and biodiversity not very positive.

\section{REFERENCES}

Adanson P.M., 1791. Description d'un arbre d'un genre nouveau appelé Baobab, observé au Sénégal. Histoire de l'Acadamie Royale des Sciences (Paris), 1791: 218-243.

Baillon H.E., 1876. Adansonia madagascariensis. Adansonia, 11: 251.

Baillon H.E., 1890. Sur les Baobabs de Madagascar. Bulletin Mensuel de la Société Linnéenne de Paris, 2: 844-846
Baum D.A., 1995. A systematic revision of Adansonia (Bombacaceae). Annals of the Missouri. Botanical Garden, 82: 440-470.

Capuron R., 1960. Contributions à l'étude de la flore forestière de Madagascar. Notulae Systematicae (Paris), 16: 60-80.

Mueller F von., 1857. New genera and species. Hooker's Journal of Botany, Kew Gardens Miscellanea, 9: 14.

Mueller F von., 1858. Botanical report on the North Australian exploring expedition. Proceedings of the Linnean Society of London (Botany), 2: 140.

Ravaomanalina H. \& Razafimanahaka J., 2016. Adansonia grandidieri. The IUCN Red List of Threatened Species 2016: e.T30388A64007143. http://dx.doi.org /10.2305/IUCN.UK.2016-2.RLTS.T30388A6400714 3.en. Downloaded on 24 March 2018.

Vieilledent G., Cornu C., Sanchez A.C., Leong Pock-Tsy J.M. \& Danthu P., 2013. Vulnerability of baobab species to climate change and effectiveness of the protected area network in Madagascar: Towards new conservation priorities. Biological Conservation, 166: 11-22. DOI: 10. 1016/ j.biocon.2013.06.007.

Wickens G.E. \& Lowe P., 2008. The Baobabs: Pachycauls of Africa, Madagascar and Australia. London: Springer,

World Conservation Monitoring Centre, 1998a. Adansonia $z a$. The IUCN Red List of Threatened Species 1998:e.T37680A10066170. DOI: 10.2305/IUCN. UK.1998.RLTS.T37680A10066170.en. Downloaded on 26 September 2018.

World Conservation Monitoring Centre, 1998b. Adansonia rubrostipa. The IUCN Red List of Threatened Species 1998: e.T37679A10065959. DOI: 10.2305 /IUCN.UK.1998.RLTS.T37679A10065959.en. Downloaded on 26 September 2018.

World Conservation Monitoring Centre, 1998c. Adansonia madagascariensis. The IUCN Red List of Threatened Species 1998. DOI:10.2305/IUCN.UK.1998. RLTS.T37681A10066258.en. Downloaded on 26 September 2018.

World Conservation Monitoring Centre, 1998d. Adansonia perrieri. The IUCN Red List of Threatened Species 1998:e.T33612A9796654. DOI: 10.2305/ IUCN.UK.1998.RLTS.T33612A9796654.en. Downloaded on 26 September 2018.

World Conservation Monitoring Centre, 2017. Adansonia suarezensis. The IUCN Red List of Threatened Species 2017: e.T30389A64366973. DOI:10.2305/ IUCN.UK.2017-3.RLTS.T30389A64366973.en. Downloaded on 26 September 2018. 